\title{
PROJEKTY DIGITALIZACYJNE ARCHIWALIÓW POLICJI PAŃSTWOWEJ Z LAT 1918-1939 W ARCHIWUM AKT NOWYCH W WARSZAWIE
}

\begin{abstract}
A rchiwa państwowe coraz większą rolę przykładają do procesu digitalizacji. Jak wiadomo materiały archiwalne udostępniane w Internecie cieszą się coraz większą popularnością wśród użytkowników, którzy dzięki temu mogą korzystać z interesujących ich jednostek archiwalnych w formie elektronicznej bez konieczności odwiedzania pracowni naukowych poszczególnych archiwów. W niniejszym tekście postanowiono ukazać digitalizację archiwaliów Policji Państwowej, które przechowywane są w Archiwum Akt Nowych w Warszawie (AAN).

Ministerstwo Kultury i Dziedzictwa Narodowego w latach 2011-2015 realizowało Wieloletni Program Rządowy Kultura +. Jego celem była poprawa dostępu do kultury oraz aktywnego uczestnictwa w życiu kulturalnym kraju. Przyczynić miała się do tego m.in. digitalizacja zasobów instytucji kulturalnych, tj. bibliotek, muzeów i archiwów w naszym kraju ${ }^{1}$.

Narodowy Instytut Audiowizualny był operatorem Priorytetu „Digitalizacja” programu Kultura+. Do najważniejszych celów operacyjnych wspomnianego programu należało:
\end{abstract}

${ }^{1}$ http://www.mkidn.gov.pl/pages/strona-glowna/finanse/program-wieloletni-kultura.php (dostęp 17 VII 2016 r.) 
- „zorganizowanie sieci pracowni digitalizacyjnych w Centrach Kompetencji i innych dużych ośrodkach, która znacząco przyspieszy digitalizację zasobów kulturowych,

- digitalizację zasobów dziedzictwa kulturowego w tym: materiałów bibliotecznych, muzealiów, zabytków, archiwaliów oraz materiału audiowizualnego,

- zorganizowanie sieci profesjonalnych repozytoriów cyfrowych w Centrach Kompetencji i innych dużych ośrodkach, umożliwiających właściwe przechowywanie zdigitalizowanych zbiorów,

- udostępnianie zbiorów za pośrednictwem Internetu w postaci cyfrowych muzeów, bibliotek, archiwów, rejestrów, ewidencji, kolekcji zabytków i wortali audiowizualnych,

- zwiększenie dostępności zbiorów polskich muzeów, bibliotek, archiwów, zbiorów audiowizualnych i zasobów zabytków"2.

- Możliwość dofinansowania poprzez udział w Priorytecie „Digitalizacja” dotyczyła przede wszystkim:

- „tworzenia infrastruktury technicznej dla zasobów cyfrowych poprzez: wyposażenie pracowni digitalizacji w skanery, sprzęt komputerowy, urządzenia do masowego przechowywania i udostępniania danych oraz oprogramowanie,

- digitalizacji zasobów kultury i dziedzictwa narodowego w tym muzealiów, zabytków, materiałów archiwalnych, zbiorów bibliotecznych oraz materiałów audiowizualnych,

- udostępnianie oraz przechowywanie zasobów cyfrowych poprzez prowadzenie archiwów cyfrowych, bibliotek cyfrowych, wirtualnych muzeów oraz mediatek cyfrowych"3.

Ubiegającymi się o dofinansowanie mogły być państwowe instytucje kultury, samorządowe instytucje kultury oraz archiwa państwowe.

AAN zgodnie z obowiązującym Statutem z dn. 29 VII 2016 r. stanowiącym Załącznik do Decyzji nr 18 Naczelnego Dyrektora Archiwów Państwowych z dn. 28 VII 2016 r. posiada Sekcję Reprograficzną i Digitalizacji, która wchodzi w skład Oddziału IV - Informacji Naukowej i Udostępniania Zasobu ${ }^{4}$. W 2011 r.

\footnotetext{
2 http://www.nina.gov.pl/programy-ministra/wieloletni-program-rz\%C4\%85dowy-kulturaplus/ (dostęp 31 VII 2016 r.)

${ }^{3}$ Tamże.

${ }^{4}$ Archiwum Akt Nowych w Warszawie (dalej AAN), Registratura własna, Decyzja nr 18 Naczelnego Dyrektora Archiwów Państwowych z dn. 29 VII 2016 r. w sprawie nadania statutu Archiwum Akt Nowych.
} 
złożony został wniosek na budowę pracowni digitalizacyjnej. Środki miały pochodzić z Wieloletniego Programu Rządowego Kultura +. Po otrzymaniu funduszy pracownia została utworzona zgodnie z Zarządzeniem Naczelnego Dyrektora Archiwów Państwowych nr 13 z dn. 29 VI 2011 r. Dzięki wspomnianym środkom AAN zakupiło wówczas dwa skanery SMA Scan Master A1 i A2, dwa komputery przystosowane do obróbki grafiki, dwa monitory do grafiki firmy EIZO oraz urządzenia do przechowywania zasobu cyfrowego. Tym samym AAN mogło rozpocząć digitalizację materiałów archiwalnych własnego zasobu ${ }^{5}$. Następnie archiwum zakupiło nowe skanery, ploter, stacje robocze do skanerów wraz z UPS, macierz dyskową z 2 UPS-ami, moduł do biblioteki taśmowej oraz oprogramowanie do obróbki grafiki. Digitalizacja w AAN realizowana jest w oparciu o obowiązujące standardy digitalizacji: Katalog Dobrych Praktyk Digitalizacji Materiałów Archiwalnych ${ }^{6}$ oraz Zarządzenie nr 14 Naczelnego Dyrektora Archiwów Państwowych z dn. 31 VIII 2015 r. w sprawie digitalizacji zasobu archiwalnego archiwów państwowych?

W 2014 r. AAN złożyło wniosek do Narodowego Instytutu Audiowizualnego o środki na projekt digitalizacyjny archiwaliów Policji Państwowej (1918-1939), który wiązał się także z zatrudnieniem dodatkowych pracowników i konserwacją materiałów archiwalnych wchodzących w skład powyższego zespołu archiwalnego. Zespół Komendy Głównej Policji Państwowej, który jako pierwszy miał zostać zdigitalizowany liczy 2233 j.a., co stanowi 29 m.b. w zasobie AAN ${ }^{8}$. W niniejszym projekcie zaplanowano skanowanie 319 tys. stron do formatu bezstratnego, kontrolę jakości, zabezpieczenie kopii wzorcowych we współpracy z Narodowym Archiwum Cyfrowym, opracowanie informacji o zespole w ZoSIA, przetworzenie skanów do celów udostępniania, udostępnienie ich w serwisie szukajwarchiwach.pl, a także utworzenie z wybranych dokumentów tekstowych formatu PDF. Zaplanowano również utworzenie portalu informacyjnego, który będzie zawierał wybrane kolekcje tematyczne związane z Policją Państwową.

${ }^{5}$ AAN, Registratura własna, Sprawozdanie z działalności Archiwum Akt Nowych w 2012 r., s.17.

${ }^{6}$ Katalog Dobrych Praktyk Digitalizacji Materiałów Archiwalnych, http://www. nina.gov.pl/media/43762/katalog-praktyk-i-standard\%C3\%B3w-digitalizacji-materia\%C5\%82\%C3\%B3w-archiwalnych.pdf (dostęp 5 XI 2016 r.)

7 Zarządzenie nr 14 Naczelnego Dyrektora Archiwów Państwowych z dn. 31 VIII 2015 r. w sprawie digitalizacji zasobu archiwalnego archiwów państwowych, https:// www.archiwa.gov.pl/images/docs/akty_normatywne/zarz_14-2015.pdf (dostęp 5 XI 2016 r.)

${ }^{8}$ AAN, Registratura własna, Wniosek o dofinansowanie zadania w ramach Programu Wieloletniego Kultura Priorytet „Digitalizacja”, s. 1-2. 
Dzięki temu projektowi planowano umożliwić dotarcie do tych, materiałów archiwalnych przez badaczy z całego świata, a także scalić rozproszone akta policyjne z różnych archiwów w naszym kraju, jak i poza jego granicami ${ }^{9}$. Należy pamiętać, że akta Komendy Głównej Policji Państwowej w czasie II wojny światowej zostały w bardzo dużym stopniu zniszczone.

W skład zespołu Komendy Głównej Policji Państwowej wchodzą materiały archiwalne dotyczące różnych zagadnień politycznych i społecznych II RP. Ogólny stan zachowania dokumentacji jest dobry, jednakże ze względu na dużą częstotliwość udostępniania, zespół narażony jest na szybką degradację. Digitalizacja zespołu miała doprowadzić do jego pełnej dostępności dla potencjalnego użytkownika, a także zabezpieczyć akta. Umieszczenie w Internecie materiałów archiwalnych miało przynieść korzyść także osobom niepełnosprawnym, jak również instytucjom kultury, które będą mogły wykorzystać kopie cyfrowe do przygotowywania wystaw, katalogów, czy innego rodzaju pomocy multimedialnych.

Materiały archiwalne będą bezpłatnie udostępnione w Internecie w serwisie szukajwarchiwach.pl Możliwe zatem jest ich przeglądanie bez konieczności logowania, pobierania, wykorzystywania i przetwarzania. Oprócz tego kopie cyfrowe będą dostępne na stronie AAN, na Facebooku, Google +, a także na stronach tematycznych poświęconych historii policji.

Z niniejszym tematem i korzystaniem ze zdigitalizowanych akt związane są również stowarzyszenia, które m.in. zajmują się historią formacji policyjnych. Do najważniejszych z nich należy zaliczyć: Międzynarodowe Stowarzyszenie Policji IPA - International Police Association, oraz Ogólnopolskie Stowarzyszenie „Rodzina Policyjna 1939 r.”10.

W realizację niniejszego projektu zostały zaangażowane także: Fundacja Źródła Pamięci, Narodowe Archiwum Cyfrowe (NAC), Muzeum Historii Polski oraz Komenda Główna Policji. Do najważniejszych form współpracy z Fundacją Źródła Pamięci należy zaliczyć pomoc przy opracowaniu kampanii informacyjnej na temat opracowanych zasobów cyfrowych i archiwalnych. NAC miało zająć się archiwizacją kopii zabezpieczających, umieszczaniem opisu zdigitalizowanych materiałów archiwalnych w serwisie ZoSIA, a także udostępnianiem kopii cyfrowych na stronie szukajwarchiwach.pl Z kolei Muzeum Historii Polski współpracowało z AAN przy opracowaniu koncepcji publicznego zaprezentowania

9 Tamże, s.3.

${ }^{10}$ http://www.ipapolska.pl/ipa/stowarzyszenie/10,IPA-podstawowe-informacje. html (dostęp 16 VII 2016 r.) 
wybranych materiałów archiwalnych z omawianego zespołu. Ostatni podmiot współpracujący tj. Komenda Główna Policji doradzała w kwestiach popularyzacji materiałów wytworzonych w ramach powyższego projektu.

Należy pamiętać, że projekt w swoim podstawowym założeniu uwzględniał potrzeby naukowe różnych grup użytkowników. Potencjalnymi odbiorcami zdigitalizowanych materiałów archiwalnych są badacze historii II RP, studenci, doktoranci, nauczyciele akademiccy, nauczyciele szkół średnich, gimnazjalnych, jak również podstawowych. Tematyka powyższych archiwaliów policyjnych obejmuje przede wszystkim: pracę kobiet w policji, sport, politykę kadrową, przestępczość, mniejszości narodowe II RP, walkę o niepodległość, historię życia codziennego, a także martyrologię w czasie II wojny światowej.

Umowa dotycząca dofinansowania zadań w ramach Programu/Priorytetu (Wieloletni Program Rządowy Kultura +/ Digitalizacja) ze środków finansowych Programu Wieloletniego Kultura + została zawarta 24 IX 2014 r. pomiędzy Narodowym Instytutem Audiowizualnym a $\mathrm{AAN}^{11}$. Środki przyznane na realizację niniejszego zadania wyniosły 273 tys. zł. Termin realizacji zadania został ustalony w okresie od 1 IX 2014 do 31 XII 2015 r. ${ }^{12}$ Środki finansowe zostały przekazane przez Ministerstwo Kultury i Dziedzictwa Narodowego za pośrednictwem Naczelnej Dyrekcji Archiwów Państwowych ${ }^{13}$. AAN zostało zobowiązane do przedstawienia sprawozdania cząstkowego, raportu częściowego oraz końcowego ${ }^{14}$.

W pierwszym roku projektu wydatki oszacowano na kwotę 35 413,44 zł, z kolei w 2015 r. na 234 024,45 zł. Szczegółowy podział kosztów za rok 2014 rozkładał się następująco: na konserwację przeznaczono 27 517,20 zł, zaś na nadzór merytoryczny projektu 7 896,24 zł.

W roku kolejnym zaś przeznaczono: na digitalizację 115989 zł, na konserwację 11 835,45 zł, na opracowanie metadanych i portal informatyczny wraz z edukacyjną bazą danych (kolekcje tematyczne) 98,2 tys. zł oraz na nadzór merytoryczny projektu 8 tys. zł.

11 AAN, Registratura własna, Umowa Nr 00123/14/NInA i AAN Nr 86/2014 z dn. 24 IX 2014 r. dotycząca dofinansowania zadań w ramach Programu/Priorytetu (Wieloletni Program Rządowy Kultura +/ Digitalizacja) ze środków finansowych Programu Wieloletniego Kultura +, s. 1.

${ }^{12}$ Tamże, $\S 1$.

13 Tamże, $\S 2$.

14 Tamże, $\S 7$. 
Szczegółowy harmonogram realizacji zadania został podzielony na trzy etapy: przygotowawczy, realizacji i podsumowania. W etapie przygotowawczym wyodrębniono:

- „opracowanie wymogów do zamówień publicznych oraz specyfikacji (zasób, metoda opracowania, jakość) w zakresie konserwacji, opracowania metadanych, digitalizacji, budowy portalu informatycznego i edukacyjnej bazy danych oraz usługi nadzoru merytorycznego i koordynacji projektu,

- $\quad$ konkursy ofert na usługi w zakresie konserwacji, opracowania metadanych, budowy portalu informatycznego i edukacyjnej bazy danych oraz usługi nadzoru merytorycznego i koordynacji projektu. Rozstrzygnięcie konkursów, wybór wykonawców i podpisanie umów,

- przetarg na usługę digitalizacji. Rozstrzygnięcie przetargu, wybór wykonawcy i podpisanie umowy"15.

- W etapie realizacji wyodrębniono:

- „wykonanie konserwacji materiałów. Kontrolę jakości przeprowadzoną przez wnioskodawcę i odbiór usługi (etap 1),

- wykonywanie nadzoru merytorycznego i koordynowanie działań w projekcie,

- $\quad$ wykonywanie konserwacji materiałów. Kontrolę jakości przeprowadzoną przez wnioskodawcę i odbiór usługi (etap 2),

- wykonanie opracowania metadanych zasobu (uzupełnienie i migracja). Kontrola jakości przeprowadzona przez wnioskodawce i odbiór usług,

- budowa portalu informatycznego i edukacyjnej bazy danych,

- wykonanie digitalizacji zasobu. Archiwizacja kopii cyfrowych w CRC (Centralne Repozytorium Cyfrowe) NAC"16.

- Z Z kolei w ostatnim etapie podsumowania wyszczególniono:

- „rozliczenie projektu,

- sprawozdanie z realizacji"17.

W dniu 29 I 2016 r. został złożony raport końcowy z zadania Digitalizacja archiwaliów Policji Państwowej 1918-1939 ${ }^{18}$. Pierwszy rok trwania projektu

${ }^{15}$ AAN, Registratura własna, Wniosek o dofinansowanie zadania w ramach Programu Wieloletniego Kultura Priorytet „Digitalizacja”, s. 10.

16 Tamże, s. 10.

17 Tamże, s. 10.

${ }^{18}$ AAN, Registratura własna, Raport końcowy z wykonania zadania w ramach Programu PW Kultura +/Digitalizacja ze środków Ministra Kultury i Dziedzictwa Narodowego „Digitalizacja archiwaliów Policji Państwowej 1918-1939, s. 1. 
przebiegał pod kątem przygotowania konserwatorskiego materiałów archiwalnych oraz przeprowadzenia kontroli jakości skanów. W tym stadium również zaproszono do współpracy NAC i Fundację Źródła Pamięci. Od października 2014 r. w projekt zaangażowanych zostało sześć osób tworzących zespół konserwatorski, które na co dzień pracują w AAN. Miesiąc później do powyższej grupy dołączyło siedem osób zajmujących się opracowaniem archiwalnym, digitalizacją oraz tworzeniem serwisów internetowych. Dzięki temu możliwe stało się przygotowanie ofert z zakresu działań związanych z opracowaniem metadanych oraz stworzeniem specyfikacji dla serwisu internetowego, za pośrednictwem którego będzie publikowany opracowany zespół.

Prace konserwatorskie zostały podzielone na dwie grupy: ze względu na zakres i typ prac. Priorytetem dla zespołu konserwatorów stała się konserwacja tej części akt zasobu, która miała poprawić czytelność tekstu, jak również zachowanie i naprawienie uszkodzonych marginesów materiałów archiwalnych wchodzących w skład zespołu Komendy Głównej Policji Państwowej. W samym 2014 r. do digitalizacji zostało przygotowane ponad 12,5 m.b. akt. Wszystkie te zadania zostały najpierw zatwierdzone przez kierownika Oddziału VII Konserwacji, a następnie przez osobę odpowiedzialną za cały projekt - zastępcę dyrektora AAN do spraw administracyjno-inwestycyjnych ${ }^{19}$.

W 2015 r. realizacja projektu objęła przede wszystkim wykonanie dalszej konserwacji materiałów archiwalnych, opracowanie metadanych, przeprowadzenie postępowania przetargowego na digitalizację, budowę portalu informatycznego, digitalizację zasobu oraz archiwizację kopii cyfrowych w Centralnym Repozytorium Cyfrowym NAC. W omawianym roku do współpracy przyłączyło się Muzeum Historii Polski w Warszawie i Komenda Główna Policji. Do końca lutego 2015 r. miała miejsce konserwacja kolejnych 5,5 m.b. akt. W dniu 28 II 2015 r. została zakończona również kontrola jakości zdigitalizowanych obiektów. Opracowanie i uzupełnienie metadanych wykonywane przez Fundację Źródła Pamięci zostało odebrane przez AAN w dwóch terminach, 30 V i 30 VI 2015 r. Tego samego dnia została również podpisana umowa z firmą Mikrofilm Service Buczek Jerzy, która zajęła się usługą digitalizacji materiałów archiwalnych. W kwestii budowy portalu informatycznego zadanie zostało podzielone na trzy części. Do $31 \mathrm{~V} 2015 \mathrm{r}$. miała miejsce iteracja początkowych prac programistycznych, tj. utworzenie systemu autoryzacji dostępu oraz logowania do systemu dla administratora oraz operatorów treści. W drugim etapie, trwającym do 30 VI 2015 r., stworzono interfejs narzędziowy i graficzny dla systemu. W ostatnim etapie, tj.

\footnotetext{
19 Tamże, s. 4.
} 
30 IX 2015 r. nastąpił odbiór całego zadania, testowanie portalu oraz szkolenie. W ramach zadania udostępnione zostały wybrane jednostki archiwalne oraz stworzono cztery kolekcje tematyczne, które znajdują się pod adresem http:// www.policja1918-1939.pl. Digitalizacja zespołu podzielona została na sześć etapów: cztery etapy dotyczyły odbioru kolejnych partii skanów, etap kolejny polegał na odbiorze kopii użytkowych, a ostatni na wykonaniu OCR skanów. 7 XII 2015 r. kopie cyfrowe zostały przekazane do Centralnego Repozytorium Cyfrowego NAC. Sprawdzenie i opublikowanie materiałów na stronie szukajwarchiwach.pl stało się możliwe dopiero w pierwszym kwartale 2016 roku. Efektem projektu była digitalizacja 1162 j.a. (łącznie 180213 skanów) ${ }^{20}$. Zespół archiwalny Komendy Głównej Policji Państwowej składa się z części aktowej i części kartotecznej w skład której wchodzą m.in. akta osobowe. Digitalizacji został poddany zespół od sygnatury 1 do 1162 bowiem tyle funduszy uzyskało AAN na ten proces.

Pod adresem http://aan-prod.iterato.rs/ ma powstać i funkcjonować portal, który będzie składał się z kartoteki, zasobów, kolekcji oraz map jednostek policji. Wspomniana kartoteka ma być zbudowana z następujących elementów: nazwiska, imienia, stopnia służbowego, funkcji/jednostki organizacyjnej oraz miasta $^{21}$. Obecnie serwis nie jest jeszcze dostępny dla użytkowników.

AAN w styczniu 2015 r. złożyło kolejny wniosek do Narodowego Instytutu Audiowizualnego o nazwie Digitalizacja archiwaliów Policji 1918-1939 (finalizacja) ${ }^{22}$. Niestety, nie udało się uzyskać finansowania na dokończenie tego projektu.

Celem projektu miała stać się całościowa cyfryzacja materiałów archiwalnych jednostek terenowych przedwojennej Policji Państwowej, w szczególności tych komend i posterunków, które obecnie znajdują się poza granicami naszego kraju oraz tych, które nie zostały ujęte we wniosku złożonym w 2014 r. Postanowiono poddać digitalizacji następujące zespoły archiwalne z zasobu AAN o kolejnych numerach: 1388 - Komenda Wojewódzka Policji Państwowej w Kielcach, 1389 Komenda Wojewódzka Policji Państwowej w Krakowie, 1390 - Komenda Wojewódzka Policji Państwowej w Lublinie, 1391 - Komenda Wojewódzka Policji Państwowej w Łodzi, 1392 - Komenda Wojewódzka Policji Państwowej w Toruniu, 1393 - Komenda Wojewódzka Policji Państwowej w Poznaniu, 1394 - Zbiór akt komend Policji państwowej województwa śląskiego, 1395 - Komenda Woje-

20 Tamże, s. 5.

21 http://aan-prod.iterato.rs/kartoteki/funkcjonariusze (dostęp 31 VII 2016 r.)

22 AAN, Registratura własna, Wniosek o dofinansowanie zadania w ramach Programu Wieloletniego Kultura Priorytet „Digitalizacja”, Digitalizacja archiwaliów Policji 1918-1939 (finalizacja), edycja 2015, s. 2. 
wódzka Policji Państwowej w Warszawie, 1404 - Dyrekcja Policji w Katowicach, 1558 - Komenda Wojewódzka Policji Państwowej w Białymstoku, 2005 - Komenda Wojewódzka Policji Państwowej w Tarnopolu, 2006 - Posterunek Policji Państwowej w Germakówce, 2007 - Komenda Powiatowa Policji Państwowej w Tarnopolu, 2008 - Komenda Powiatowa Policji Państwowej w Podhajcach, 2009 - Komenda Wojewódzka Policji Państwowej w Łucku, 2010 - Komenda Powiatowa Policji Państwowej w Łucku, 2011 - Komenda Powiatowa Policji Państwowej w Krzemieńcu, 2012 - Komenda Powiatowa Policji Państwowej w Równem, 2013 - Komenda Powiatowa Policji Państwowej w Zdołbunowie, 2014 - Powiatowa Policja Państwowa w Małyńcu, 2015 - Komenda Wojewódzka Policji Państwowej w Wilnie, 2016 - Komenda Powiatowa Policji Państwowej w Święcianach, 2017 - Komenda Wojewódzka Policji Państwowej w Nowogródku, 2018 - Komenda Wojewódzka Policji Państwowej w Brześciu, 2019 Komenda Wojewódzka Policji Państwowej w Stanisławowie, 2020 - Komenda Powiatowa Policji Państwowej w Tłumaczu, 2021 - Komenda Wojewódzka Policji Państwowej we Lwowie, 2022 - Komenda Powiatowa Policji Państwowej w Dobromilu, 2023 - Komenda Powiatowa Policji Państwowej w Jarosławiu, 2024 - Komenda Powiatowa Policji Państwowej w Łańcucie, 2025 - Komisariat Policji Państwowej Miasta Lwowa, 2026 - Komenda Powiatowa Policji Państwowej w Przemyślu, 2027 - Komenda Powiatowa Policji Państwowej w Przeworsku, 2028 - Komenda Powiatowa Policji Państwowej w Rzeszowie, 2029 - Komenda Powiatowa Policji Państwowej w Sanoku oraz 2067 - Posterunek nr 2 Policji Państwowej w Czeremsze ${ }^{23}$.

Tak jak i poprzednio całe zadanie miało objąć przygotowanie konserwatorskie, bieżącą konserwację materiałów archiwalnych, skanowanie do formatu bezstratnego z kontrolą jakości 190000 stron, zabezpieczenie kopii wzorcowych w Centralnym Repozytorium Cyfrowym NAC, opracowanie informacji o 1744 j.a. w ZoSIA, przetworzenie skanów, jak również ich publikację na szukajwarchiwach.pl oraz kolekcjach tematycznych utworzonego portalu. Oprócz tego większa uwaga miała zostać zwrócona na budowę narzędzi informatycznych, które miałyby eksplorować, przetwarzać i realizować scenariusze edukacyjne z wykorzystaniem zasobów cyfrowych: interaktywnej mapy zasobów i danych oraz hiperkatalogu ${ }^{24}$.

\footnotetext{
${ }^{23}$ AAN, Registratura własna, Plan działalności digitalizacyjnej 2014-2016, s. 1-2.

${ }^{24}$ AAN, Registratura własna, Wniosek o dofinansowanie zadania w ramach Programu Wieloletniego Kultura Priorytet „Digitalizacja”, Digitalizacja archiwaliów Policji 1918-1939 (finalizacja), edycja 2015, s. 3.
} 
Całkowity koszt zadania miał wynieść 382,8 tys. zł. Na konserwację wyodrębniono 55 tys. zł, na digitalizację 185 tys. zł, opracowanie metadanych oraz kontrolę jakości 50 tys. zł, przygotowanie skanów do publikacji w serwisie szukajwarchiwach.pl 2 tys. zł, narzędzia informatyczne (mapa interaktywna, aplikacja mobilna, hiperkatalog z kolekcjami tematycznymi 90 tys. zł oraz dwa nośniki danych (zewnętrzne dyski przenośne) do przekazania zbiorów 800 zł²5.

Realizacja powyższego zadania miała trwać od kwietnia do grudnia 2015 r. Od 1 do 15 IV 2015 r. miał rozpocząć się etap przygotowawczy skupiający się na opracowaniu szczegółowej specyfikacji dla zadań związanych z konserwacją, opracowaniem metadanych, digitalizacją, budową narzędzi informatycznych (hiperkatalog, interaktywna mapa zasobów i danych, aplikacja mobilna). Od 16 IV do 15 VII 2015 r. miał mieć miejsce wybór wykonawców poszczególnych zadań. Następnie, od 16 VII do 30 X 2015 r. zaplanowano etap realizacji, który polegać miał na: wykonaniu konserwacji zasobu, kontroli jakości przeprowadzonej przez wnioskodawcę, odbiór usługi, wykonanie opracowania metadanych dla zasobu, publikację opisów w Zintegrowanym Systemie Informacji Archiwalnej, wykonanie narzędzi informatycznych (mapy interaktywnej, aplikacji mobilnej, hiperkatalogu). Od 17 VIII aż do 30 XI 2015 r. miała odbywać się digitalizacja zasobu, przygotowanie skanów do publikacji na szukajwarchiwach.pl, ich publikacja oraz archiwizacja kopii cyfrowych w Centralnym Repozytorium Cyfrowym NAC. Do ostatnich czynności, jakie miały wejść w poczet realizacji powyższego zadania zaliczono działania informacyjne i popularyzatorskie w określonych kanałach informatycznych. Do końca grudnia 2015 r. miało zostać sporządzone rozliczenie projektu oraz sprawozdanie z jego realizacji ${ }^{26}$. Należy w tym miejscu żałować jedynie, że nie udało się pozyskać środków finansowych na sfinalizowanie akt Policji Państwowej w okresu międzywojennego.

Podsumowując, digitalizacja archiwaliów Policji Państwowej 1918-1939 przyniosła ogromne korzyści. Obok zabezpieczenia materiałów archiwalnych postanowiono udostępnić je dla użytkowników w Internecie. Większość z nich udostępniona jest na stronie internetowej szukajwarchiwach.pl Oprócz tego cały czas trwają prace nad ukończeniem portalu z kolekcjami tematycznymi. Materiałów archiwalnych Komendy Głównej Policji Państwowej 1918-1939 nie zabraknie również na Facebook'u, Google + czy serwisach poświęconych policji. Cyfrowe kopie mogą przyczynić się do tworzenia wystaw w samym AAN, jak i poza jego siedzibą. Ponadto mogą one posłużyć jako materiały promocyjne.

\footnotetext{
25 Tamże, s. 8-9.

26 Tamże, s. 9.
} 